\title{
Effect of Soil Properties on forms of potassium in Some Soils of Homs Governorate
}

\author{
Sameer M. Shamsham ${ }^{1}$, Reem F. Nasra ${ }^{2}$, and Rawaa Z. Ayoush ${ }^{3}$ \\ ${ }^{1}$ Soil Sciences and land Reclamation Department, Faculty of Agriculture, Al-Baath University, Syria, sshamsham@hotmail.com \\ ${ }^{2}$ Soil Sciences and land Reclamation Department, Faculty of Agriculture, Al-Baath University, Syria, rimannn411@gmail.com \\ ${ }^{3}$ Department of Field crops, Faculty of Agriculture, Al-Baath University, Syria, rawaayoush1987@gmail.com \\ * Corresponding Author: Reem F. Nasra, email: rimannn411@gmail.com \\ Published online: 31 August 2019
}

Abstract- The study was conductedto determine the forms of potassium in soils (water soluble K, exchangeable $\mathrm{K}$, available $\mathrm{K}$, non-exchangeable $\mathrm{K}$, lattice $\mathrm{K}$, total $\mathrm{K}$ ) in some of Homs soils using standard laboratory procedures. The soils were ASHRAFIA, MARANA, MOUKHTARIA, ROUGHAMA, SANKARY, MASTORAH, SADAD, ARQAYA, GDAIDA, SAYED. The samples were analyzed for mechanical composition of soil viz., sand, silt, clay and chemical composition viz., pH, EC, O.M., and analyzed the different forms of potassium. The amount of water soluble, exchangeable, available, nonexchangeable, lattice and total-K in soils; ranged from $1.49-145.92,244.46-787.71,245.95-954.83$, $11.10-836.57,3678.08-18041.08$ and $4583.00-19643 \mathrm{mg} / \mathrm{Kg}$. The study showed that lattice $\mathrm{K}$ is the largest part of total $\mathrm{K}$ in the soils, while the water soluble $\mathrm{K}$ is the lowest part of total $\mathrm{K}$. The total $\mathrm{K}$ and lattice $\mathrm{K}$ showed significant and positive correlation with $\mathrm{pH}$. Water-soluble $\mathrm{K}$ concentrations positively correlated with organic matter and sand. The available K showed significant and positive correlation with sand.

Keywords - Soil, Potassium, Forms, Non-exchangeable K, Lattice, Organic matter, Homs.

\section{Introduction}

Potassium enters into the synthesis of all living cells and is needed in large quantities by plants, animals and humans [13]. Potassium is an essential element for the growth of all plants[6], because plays an important role in plant nutrition and physiology.Many plants absorb more potassium than nitrogen and phosphorus. $\mathrm{K}$ is depleted in great amount in intensive agriculture[32]. potassium increases resistance of plants to stress factors, such as pathogens, pests, and draught [20]. K enhance photosynthesis, controls stomata opening, improves $\mathrm{N}$ employment. It Also affects the microbial activity in the rhizosphere [23; 36]. Therefore, the lack of this elementlead toprevent of plant growth and thus reductionin field yield [42]. Potassium is found in large quantities in the soil, where the concentrations ranging between $0.4-30$ $\mathrm{g} \mathrm{k} \mathrm{g}-1$ with an average of $14 \mathrm{~g} \mathrm{~kg}-1$ [5; 15].feldspar and mica are the most commonminerals containing $\mathrm{K}$. In general, plants mainly uptake available $\mathrm{K}$ (water soluble, exchangeable) which isbound to the clay minerals and organic matters by electrostatic forces. available $\mathrm{K}$ formabout $1-2 \%$ of the total $\mathrm{K}$ in soil.[17] The plants can also absorb $\mathrm{K}$, which is more strongly associated with the soil minerals than the Kex [28, 29 ], which is fixed within clay minerals (illite, vermiculite and chlorite), which are consist of sheets of silica and alumina [40], and held between adjacenttetrahedral layers of dioctahedral and trioctahedral micas, vermiculites [19, 24]. This form of K, is slowly available for crops, is called as nonexchangeable $\mathrm{K}$ (Kne), [9, 25, 29, 30] have found that plants acquire a large proportion of their requirement of potassium from this form (Kne) .Potassium is formed in soil from the degradation of rocks containing $\mathrm{K}$ bearing minerals. These minerals are completely resistant to weathering factors and therefore release $\mathrm{K}$ very slowly[11],According to [17], they account for $90-98 \%$ of total $\mathrm{K}$ in soil, where they are not available fractions. However, availablepotassium are slowly depress after long periods of agricultural production. After that cropss can only depend on the release of nonexchangable K,but [26] found that the amount of the nonexchangable potassium is insufficient to meet the requirements of plants, especially in highyielding agriculture systems. [27] reported that the water 
soluble, exchangeable, available soil $\mathrm{K}$ had positive correlation with organic carbon content, EC and CEC, whereas, lattice and total soil $\mathrm{K}$ were negatively correlated to clay content and EC. [41] reported that the electrical conductivity (EC) was significantly and positively correlated with water-soluble, available and exchangeable K. Like EC, organic carbon was also positively correlated with water soluble, available and exchangeable K. [38] found that the water soluble $\mathrm{K}$ show negative relationship with sand, Sand positive relationship with clay, organic carbon, $\mathrm{pH}, \mathrm{CaCO} 3$ and CEC. Das et al noticed that the $\mathrm{pH}$ of the soils, positive significant correlation with all the forms other than water soluble $-\mathrm{K}[10]$. Chand et al observed that the content of clay, cation exchange capacity and $\mathrm{pH}$ showed significant positive correlation with all fractions of $\mathrm{K}$, except water soluble $\mathrm{K}$ [7]. Arora et al found that available $\mathrm{K}$ content was positively and significantly correlated with silt, clay and CEC while negatively and significantly correlated with sand content [2]. Therefore, there was a need to study the distribution of potassium forms in the soil, in order to determine the extent of soil need for it.The study aimed at determining the distribution of $\mathrm{K}$ forms in some soil types in Homs governorate and studying the relationships between the $\mathrm{K}$ forms and the physical chemical properties of the soil.

\section{Materials and methods}

Soils surface composite samples $(0-20 \mathrm{~cm})$ of 10 soils were collected from homs governorate. The soils are the (ASHRAFIA, MARANA, MOUKHTARIA, ROUGHAMA, SANKARY, MASTORAH, SADAD, ARQAYA, GDAIDA, SAYED).The soils were air dried, crushed and sieved $(2 \mathrm{~mm})$ and stored until analysis.

\section{Laboratory analyses}

The particle-size distribution of the soils was carried out by the hydrometer method [1]. Soil $\mathrm{pH}$ in water was determined by the glass electrode $\mathrm{pH}$ (1: 2.5 , soil: water). Soil organic carbon concentration were analyzed according to procedures described by [43], while electrical conductivity (1: 2.5 , soil: water) were analyzed according to procedures described by [35], CEC were analyzed according to procedures described by [8], carbonat was determined by the calcimeter [4], active lime was analyzed according to procedures described by [12].

\section{Determination of forms of potassium}

Total $\mathrm{K}(\mathrm{Kt})$ was extracted with $\mathrm{HNO} 3$ - HClO4mixture [16]. Watersoluble K (Ks)was extracted with water (1:5, soil:water) as described by [18]. Exchangeable $\mathrm{K}(\mathrm{Ke})$ was extracted with $1 \mathrm{M}$ NH4OAc $(\mathrm{pH}=7)$. Non-exchangeable $\mathrm{K}$ (Kne) was extractedwith $1 \mathrm{~N}$ boiling $\mathrm{HNO} 3$ (1:10, soil: HNO3)[14]. Mineral Potassium (Km) was calculated from the difference between total $\mathrm{K}$ and the sum of available $\mathrm{K}$ and non-exchangeable $\mathrm{K}$. All forms of Potassium was measured by flame photometry.[31]

\section{Statistical analyses}

A correlation analysis was carried out among different forms of potassium ( $\mathrm{Ks}, \mathrm{Ke}, \mathrm{Kav}, \mathrm{Kne}, \mathrm{Km}$ and $\mathrm{Kt}$ ) and soil properties. Statistical analyses were achieved with the SPSS 16.0.

\section{Results and Discussions}

\subsection{Physico-chemical properties of the soils}

Table. 1 shows physico-chemical properties determined in the soil. content of the soil from sand, silt and clay was ranged from 19.44 to $58.47,15.34$ to 55.97 and 21.98 to $50.4 \%$, respectively. and $\mathrm{pH}$ measured in the study ranged from 7.63 to 8 . Table.1. The CEC values werebetween 16 and $49.38 \mathrm{meq} / 100 \mathrm{~g}$. organic matter in the soils ranged between $0.88-6.55 \%$.

Table 1: physicochemical characteristics of the soils.

\begin{tabular}{|l|l|l|l|l|l|l|l|l|l|l|}
\hline Soil Series & $\mathrm{pH}$ & $\begin{array}{l}\mathrm{EC} \\
\boldsymbol{\mu} \mathbf{c} / \mathbf{c m}\end{array}$ & $\begin{array}{l}\text { Carbonat } \\
\%\end{array}$ & $\begin{array}{l}\text { Active } \\
\text { lime } \\
\%\end{array}$ & $\begin{array}{l}\text { OM } \\
(\%)\end{array}$ & $\begin{array}{l}\text { CEC } \\
\mathrm{Meq} / 100 \mathrm{~g}\end{array}$ & $\begin{array}{l}\text { Sand } \\
\%\end{array}$ & $\begin{array}{l}\text { Silt } \\
\%\end{array}$ & $\begin{array}{l}\text { Clay } \\
\%\end{array}$ & Texture \\
\hline ASHRAFIA & 8.3 & 148 & 4.98 & 4.41 & 1.21 & 49.38 & 23.14 & 26.47 & 50.4 & clay \\
\hline MARANA & 7.87 & 72 & 5.11 & 3.92 & 0.88 & 32.88 & 27.31 & 36.82 & 35.87 & $\begin{array}{l}\text { clay } \\
\text { loam }\end{array}$ \\
\hline MOUKHTARIA & 8.34 & 146.4 & 23.71 & 15.19 & 0.95 & 32.5 & 29.46 & 33.42 & 37.12 & $\begin{array}{l}\text { clay } \\
\text { loam }\end{array}$ \\
\hline ROUGHAMA & 8.35 & 127.2 & 15.51 & 7.84 & 1.6 & 27 & 26.45 & 40.8 & 32.74 & $\begin{array}{l}\text { clay } \\
\text { loam }\end{array}$ \\
\hline SANKARY & 8.6 & 300 & 36.9 & 14.95 & 1.91 & 20.88 & 22.04 & 55.97 & 21.98 & $\begin{array}{l}\text { silt } \\
\text { loam }\end{array}$ \\
\hline MASTORAH & 7.97 & 146.6 & 2 & 1.47 & 1.09 & 37.38 & 19.44 & 41.53 & 39.04 & $\begin{array}{l}\text { clay } \\
\text { loam }\end{array}$ \\
\hline SADAD & 8.36 & 709 & 51.34 & 12.01 & 1.81 & 17.75 & 35.51 & 38.02 & 26.46 & loam \\
\hline ARQAYA & 7.63 & 278 & 8.25 & 2.94 & 6.55 & 25.13 & 44.77 & 31.5 & 23.73 & loam \\
\hline
\end{tabular}




\begin{tabular}{|c|c|c|c|c|c|c|c|c|c|c|}
\hline GDAIDA & 8.39 & 260 & 9.28 & 5.15 & 4.31 & 25.38 & 58.47 & 15.34 & 26.18 & $\begin{array}{l}\text { sandy } \\
\text { clay } \\
\text { loam }\end{array}$ \\
\hline SAYED & 8.5 & 136 & 47.06 & 12.25 & 3.17 & 16 & 29.02 & 40.5 & 30.48 & $\begin{array}{l}\text { clay } \\
\text { loam }\end{array}$ \\
\hline
\end{tabular}

\section{Forms of potassium in the soils}

Table. 2 shows the concentrations of the different forms of $\mathrm{K}(\mathrm{mg} / \mathrm{kg})$ in the soils. the results indicated a significant difference in the distribution of $\mathrm{K}$ forms in the soils, This may be due to the difference in the physical and chemical characteristic of the studied soil. in the study, total $\mathrm{K}$ values ranged from 2153 to $18848 \mathrm{mg} / \mathrm{kg}$. MARANA soil, which contained the lowest soil $\mathrm{pH}$ and high clay content, showed the lowest total content of the $\mathrm{K}(\mathrm{P}<0.05)$. This corresponds to Suddhiprakarn et al, who observed that the high clay content in the soil with low soil $\mathrm{pH}$ is often related to low concentration of total potassium [39].Water soluble $\mathrm{K}$ and exchangeable $\mathrm{K}$ measured in the soils ranged from 1.49 to $145.92 \mathrm{mg} / \mathrm{kg}$ and 244.46 to 808.91 $\mathrm{mg} / \mathrm{kg}$, respectively. the water soluble and exchangeable $\mathrm{K}$ concentrations, which are available $\mathrm{K}$ according to [33],were the highest in the GDAIDA soil, while the lowest available $\mathrm{K}$ concentration was measured in the MARANA soil $(\mathrm{P}<0.05)$, This may be due to the low $\mathrm{pH}$ of this soil. The non-exchangeable $\mathrm{K}$ ranged from 11.10 to $836.57 \mathrm{mg} / \mathrm{kg}$. The results showed that the soil content ofwater soluble $\mathrm{K}$ ranged from 0.09 to $2.58 \%$ of total $\mathrm{K}$ concentrations, exchangeable $\mathrm{K}$ concentrations ranged from 2.69 to $12.15 \%$, while non-exchangeable $\mathrm{K}$, lattice $\mathrm{K}$ accounted for 0.25 to $4.50 \%, 80.97$ to $96.05 \%$ of the total $\mathrm{K}$ concentrationsrespectively, indicative that the lattice $\mathrm{K}$ concentrations constituted the highest part of the total $\mathrm{K}$ in the soils, while the water soluble $\mathrm{K}$ considered the lowest proportion of the total $\mathrm{K}$.

Table 2: different forms of potassium in the studied soils $\mathrm{mg} / \mathrm{kg}$.

\begin{tabular}{|c|c|c|c|c|c|c|c|c|c|c|c|}
\hline Soil Series & $\mathbf{K t}$ & Ks & $\begin{array}{c}\text { \% of } \\
\text { Total } \\
\text { K } \\
\end{array}$ & Ke & $\begin{array}{c}\text { \% of } \\
\text { Total } \\
\text { K } \\
\end{array}$ & Kav & $\begin{array}{c}\text { \% of } \\
\text { Total } \\
\text { K } \\
\end{array}$ & Kne & $\begin{array}{c}\text { \% of } \\
\text { Total } \\
\text { K } \\
\end{array}$ & $\mathbf{K m}$ & $\begin{array}{c}\text { \% of } \\
\text { Total } \\
\text { K } \\
\end{array}$ \\
\hline ASHRAFIA & $\begin{array}{c}11693.00 \\
\mathrm{c}\end{array}$ & $\begin{array}{c}10.77 \\
\mathrm{~g}\end{array}$ & 0.09 & $\begin{array}{c}314.69 \\
\mathrm{e}\end{array}$ & 2.69 & $\begin{array}{c}325.45 \\
\mathrm{f}\end{array}$ & 2.78 & $\begin{array}{c}428.47 \\
b\end{array}$ & 3.66 & $\begin{array}{c}10939.08 \\
\mathrm{c}\end{array}$ & 93.55 \\
\hline MARANA & $2153.00 \mathrm{e}$ & $\begin{array}{c}21.37 \\
\mathrm{e}\end{array}$ & 0.99 & $\begin{array}{c}244.46 \\
f\end{array}$ & 11.35 & $\begin{array}{c}265.83 \\
g\end{array}$ & 12.35 & $11.10 \mathrm{~d}$ & 0.52 & $1876.08 \mathrm{e}$ & 87.14 \\
\hline MOUKHTARIA & $\begin{array}{c}14078.00 \\
\mathrm{~b}\end{array}$ & $\begin{array}{c}33.29 \\
\mathrm{e}\end{array}$ & 0.24 & $\begin{array}{c}762.54 \\
a \\
\end{array}$ & 5.42 & $\begin{array}{c}795.83 \\
\mathrm{~b}\end{array}$ & 5.65 & $\begin{array}{c}360.90 \\
\mathrm{~b}\end{array}$ & 2.56 & $\begin{array}{c}12921.28 \\
\mathrm{~b}\end{array}$ & 91.78 \\
\hline ROUGHAMA & $\begin{array}{c}18583.00 \\
\mathrm{a}\end{array}$ & $\begin{array}{c}41.24 \\
\mathrm{~d}\end{array}$ & 0.22 & $\begin{array}{c}787.71 \\
\mathrm{a}\end{array}$ & 4.24 & $\begin{array}{c}828.95 \\
\mathrm{~b}\end{array}$ & 4.46 & $\begin{array}{c}836.57 \\
\mathrm{a} \\
\end{array}$ & 4.50 & $\begin{array}{c}16917.48 \\
\mathrm{a}\end{array}$ & 91.04 \\
\hline SANKARY & $\begin{array}{c}18848.00 \\
\mathrm{a}\end{array}$ & $\begin{array}{c}45.22 \\
d\end{array}$ & 0.24 & $\begin{array}{c}538.61 \\
\mathrm{c}\end{array}$ & 2.86 & $\begin{array}{c}583.83 \\
\mathrm{~d}\end{array}$ & 3.10 & $\begin{array}{c}223.10 \\
\mathrm{c}\end{array}$ & 1.19 & $\begin{array}{c}18041.08 \\
\mathrm{a}\end{array}$ & 95.71 \\
\hline MASTORAH & $4538.00 \mathrm{~d}$ & $1.49 \mathrm{~g}$ & 0.04 & $\begin{array}{c}244.46 \\
\mathrm{f}\end{array}$ & 5.58 & $\begin{array}{c}245.95 \\
\mathrm{~g}\end{array}$ & 5.62 & $62.77 \mathrm{~d}$ & 1.36 & $\begin{array}{c}4229.28 \\
d\end{array}$ & 93.02 \\
\hline SADAD & $\begin{array}{c}11163.00 \\
\mathrm{c}\end{array}$ & $27.99 \mathrm{f}$ & 0.25 & $\begin{array}{c}648.59 \\
b\end{array}$ & 5.82 & $\begin{array}{c}676.58 \\
\mathrm{c}\end{array}$ & 6.07 & $77.35 \mathrm{~d}$ & 0.70 & $\begin{array}{c}10409.08 \\
\mathrm{c}\end{array}$ & 93.24 \\
\hline ARQAYA & $4538.00 \mathrm{~d}$ & $\begin{array}{c}116.77 \\
b\end{array}$ & 2.58 & $\begin{array}{c}546.56 \\
\mathrm{c} \\
\end{array}$ & 12.15 & $\begin{array}{c}663.33 \\
\mathrm{c} \\
\end{array}$ & 14.74 & $\begin{array}{c}196.60 \\
\mathrm{c} \\
\end{array}$ & 4.29 & $\begin{array}{c}3678.08 \\
\mathrm{~d}\end{array}$ & 80.97 \\
\hline GDAIDA & $\begin{array}{c}19643.00 \\
\mathrm{a} \\
\end{array}$ & $\begin{array}{c}145.92 \\
\mathrm{a}\end{array}$ & 0.74 & $\begin{array}{c}808.91 \\
\mathrm{a} \\
\end{array}$ & 4.12 & $\begin{array}{c}954.83 \\
\mathrm{a} \\
\end{array}$ & 4.86 & $\begin{array}{c}806.10 \\
\mathrm{a} \\
\end{array}$ & 4.10 & $\begin{array}{c}17882.08 \\
\mathrm{a} \\
\end{array}$ & 91.04 \\
\hline SAYED & $\begin{array}{c}14078.00 \\
b\end{array}$ & $\begin{array}{c}70.39 \\
\mathrm{c}\end{array}$ & 0.50 & $\begin{array}{c}447.19 \\
\text { d }\end{array}$ & 3.19 & $\begin{array}{c}517.58 \\
\mathrm{e}\end{array}$ & 3.69 & $34.94 \mathrm{~d}$ & 0.25 & $\begin{array}{c}13525.48 \\
b\end{array}$ & 96.05 \\
\hline
\end{tabular}

Values followed by different letters are Statistically different $(\mathrm{P}<0.05)$. Means with similar letters are not Statistically significant at $(\mathrm{P}<0.05)$.

\section{Influence of some selected soil properties on different forms of potassium}

Table.3.shows the correlation between different forms of $\mathrm{K}$ and the physicochemical characteristics of thesoils. Soluble K forms correlated with positive correlation with organic matter $(\mathrm{r}=$ $0.879)$,Similar results were obtained by [3; 21, 27; 41], This observation may be attributed to negative charges of organic matter which have affinity for $\mathrm{K}^{+}$ions, or this is probably due to the fact with increase in organic matter in soils, the clay-humus complex become more active thereby providing more exchange sites and access to K.Soluble $\mathrm{K}$ forms significantly correlated positively with sand content, $(\mathrm{r}=0.897)$, The present finding disagreed with the finding of [38]. The concentrations of total K, and mineral $\mathrm{K}$, significantly correlated positively with soil $\mathrm{pH}$,with correlation coefficients $(\mathrm{r}=0.846,0.887: \mathrm{P}<0.01)$ respectively,Table.3. $[7 ; 10]$, also had similar observations in their studies. The correlation observed between soil $\mathrm{pH}$ and $\mathrm{Kt}$ disagreed with [37].

Additionally, the study demonstrated that available $\mathrm{K}$ significantly correlated positively with sand content $\left(\mathrm{r}=0.664^{*}\right)$, The present finding disagreed with the finding of [2;22].

Ks form andKavsignificantly correlated negatively with fine particle content (clay + silt $)(r=-0.879 ; p<0.01, r .=-0.664 ; p<$ 0.05 ) respectively, this is due to the binding of these forms in 
lattice structure of the clay minerals, they are then slowly released with time [34].

Table 3: correlation between different forms of potassium and some selected soil properties.

\begin{tabular}{|c|c|c|c|c|c|c|c|c|c|c|}
\hline & $\mathbf{p H}$ & $\mathbf{E C}$ & Carbonat & $\begin{array}{c}\text { Active } \\
\text { lime }\end{array}$ & $\mathbf{O M}$ & $\mathbf{C E C}$ & $\begin{array}{c}\text { Sand } \\
\%\end{array}$ & Silt \% & $\begin{array}{c}\text { Clay } \\
\%\end{array}$ & $\begin{array}{c}\text { clay+sil } \\
\mathbf{t}\end{array}$ \\
\hline Kt & $.864(* *)$ & 0.105 & 0.393 & 0.583 & -0.008 & -0.322 & 0.19 & 0 & -0.264 & -0.191 \\
\hline Ks & -0.051 & 0.095 & -0.022 & -0.088 & $\begin{array}{c}.879(* * \\
)\end{array}$ & -0.459 & $\begin{array}{c}.897(* * \\
)\end{array}$ & -0.502 & -0.621 & - \\
\hline Kex & 0.415 & 0.319 & 0.297 & 0.467 & 0.274 & -0.456 & 0.556 & -0.235 & -0.48 & -0.556 \\
\hline Kav & 0.359 & 0.301 & 0.259 & 0.398 & 0.41 & -0.492 & $.664\left(^{*}\right)$ & -0.304 & -0.544 & $-.664(*)$ \\
\hline Knex & 0.309 & -0.163 & -0.3 & -0.06 & 0.116 & 0.138 & 0.395 & -0.462 & 0.025 & -0.395 \\
\hline Km & $.887\left(^{* *}\right)$ & 0.108 & 0.421 & 0.606 & -0.031 & -0.329 & 0.155 & 0.036 & -0.26 & -0.155 \\
\hline
\end{tabular}

* Significant at $\mathrm{P}<0.05 * *$ significant at $\mathrm{P}<0.01$

\section{Conclusions}

The study showed the soils contain a large lattice $\mathrm{K}$ fraction $(91 \%)$ of total $\mathrm{K}$, and a smaller fraction of available forms of K.(\%6) The study displayed that the percentage of exchangeable and non-exchangeable $\mathrm{K}$ is about $7 \%$ of the total $\mathrm{K}$. However, $\mathrm{K}$ (ne) can serve as $\mathrm{K}$ reserves, where crops can rely on this form to satisfy their requirements. It is released slowly when the available $\mathrm{K}$ becomes depleted.

\section{References}

[1] Anderson J.M. and Ingram J.S.I. 1989. Tropical Soil Biology and Fertility. A handbook of methods. C.A.B. International.

[2] Arora, Sanjay and Chahal, D.S. (2003). Distribution of Available Potassium in Benchmark Soils in Relation to soil Characteristics. J. of Potassium Res. 19: 41-44.

[3] Awad, M. Y.; M. A. El-Desoky; Nadia M. Roshdi and M. A. Tantawy. 2016 Potassium Forms of ELDakhla Oasis Soils, New Valley Governorate, Egypt " J. Soil Sci. and Agric. Eng., Mansoura Univ., Vol. 7 (12): 947 - 954.

[4] BASCOMB C.L, 1961- Acalcimeter for routine use soil sample. Chem. and indust. 45, 1826-1827.

[5] Bowen HJM 1979: Environmental Chemistry of the Elements, pp. 71 - 141. Academic press Inc., London, UK.

[6] Brouder S 2011: Potassium cycling. In Soil Management: Building a Stable Base for Agriculture, Eds. Hatfield JL, Sauer TL, American Society of Agronomy and Soil Science Society of America, Madison, WI, pp. 79- 102.

[7] Chand, Subhas and Swami, B.N. (2000). Different forms of potassium in some important soils association of Bharatpur district of Rajasthan. J. of potassium Res. 16: 59-61.
[8] CHAPMAN H D, 1965-" Cation exchange capacity ". Black, C. A: Ed., American Society of Agronomy, Madison, Wis, pp 891-904.

[9] Cox AE, Joern BC, Brouder SM, Gao D 1999: Plantavailable potassium assessment with a modified sodium tetraphenylboron method. Soil Sci. Soc. Am. J., 63, 902-911. doi: 10.2136/sssaj1999.634902 x

[10] Das K., Dipak Sarkar and Nayak, D.C. (2000). Forms of potassium and their distribution in some soils representing red and laterite ecosystem of West Bengal. J. of Potassium Res. 16: 1-6.

[11] Defoer T., Budelman A., Toulmin C. Carter S. and Ticheler J. 1998. Soil fertility management in Africa: A resource guide for participatory learning and action research. A KIT Publication. pp. 3-27.

[12] DROUINEAU G, 1942- Dosage rapide du calcaireactif des sol. Nouvellesdonnees sur la reportation de la nature des fractions calcaires. Ann .Agro, 12:411- 450.

[13] Hamdallah G. 2004. Plant, Animal and Human Nutrition: An Intricate Relationship. Expert Consultation on Land Degradation and Plant, Animal and Human Nutrition, ACSAD, Damascus, Syria.

[14] Haylock O.F. 1956. A method for estimating the availability of non-exchangeable K. 6th International congress. Soil Science. 13: 403-408.

[15] Helmke P A, S parks DL2000: Potassium, Rubidium, and Cesium. Methods of Soil Analysis Part 3. Chemical Methods, pp. 559-562. SSSA Book Series. no. 5, Madison, WI .

[16] Hesse, P.R. 1971. Text Book of Soil Chemical Analysis. Williams Clows\& Sons Limited, London.

[17] Hoeft R.G., Nafziger E.D., Johnson R.R. and Aldrich S.R. 2000. Modern Corn and Soybean production. MCSP Publications. Champaign, IL. p. 353.

[18] Jackson, M.L. (1973) Soil Chemical Analysis, Prentice Hall of India Pvt Ltd., New Delhi, 1-485.

[19] Kirkman JH, Basker A, Surapaneni A, MacGregor AN 1994: Potassium in the soils of New Zealand - A review. New Zealand J. Agric. Res., 37, 207 - 227. doi:10.1080/00288233.1994.9513059

[20] Kozak M., Stêpieñ M. and Joarder A.H. 2005. Relationships between available and exchangeable 
potassium content and other soil properties. Polish Journal of Soil Science. 38(2): 1-8.

[21] Kumar J. K and Unni.S. P. K, 2018. Status and Distribution Study for Different Forms of Potassium in the Soils of Nignoti Village of Indore District of Western Madhya Pradesh, India. Int.J.Curr.Microbiol.App.Sci (2018) 7(4): 15791584.

[22] Kundu, M.C., G.C. Hazra, P.K. Biswas, S. Mondal and G.K. Ghosh (2014). Forms and distribution of potassium in some soils of Hooghly district of West Bengal. J. Crop and Weed, 10(2): 31-37.

[23] Lauchli A. and Pfluger R. 1979. Potassium transport through plant cell membranes and metabolic role of $\mathrm{K}$ in plants. Potassium Research, Review and Trends, Int. Potash Institute, Berne, Switzerland. p. 33.

[24] Martin HW, Sparks DL1985: On the behavior of nonexchangeable potassium in soils. Commun. Soil Sci. Plant Anal., 16, 133- 162. doi: 10.1080/ 00103628509367593

[25] Meyer D, Jungk A1993: A new approach to quantify the utilization of non-exchangeable soil potassium by plants. Plant Soil, 149, $235 \quad-243$. doi:10.1007/BF00016614

[26] Mikkelsen R.L. 2008. Managing Potassium for Organic Crop Production: Better crops. 92(2): 26-29.

[27] Mishra, M.K. and Shrivastava, P.C. (1991) Depthwise distribution of Forms of potassium in some soil profiles of Garhwal Himalayas. J. of Potassium Res. $7(2): 75-84$.

[28] Mitsios IK, Rowell DL 1987: Plant uptake of exchangeable and non-exchangeable potassium. I. Measurement and modelling for onion roots in a chalky boulder clay soil. J. Soil Sci., 38, $53-63$. doi:10.1111/j.1365-2389.1987.tb02122.x

[29] Moritsuka N, Yanai J, Fujii A, Sano S, Kosaki T 2003: Evaluation of readily available nonexchangeable potassium in soil by sequential extractions with 0.01 molar hydrochloric acid. Soil Sci. Plant Nutri. 49, 631-639.

[30] Moritsuka N, Yanai J, Kosaki T 2004: Possible processes releasing nonex-changeable potassium from the rhizosphere of maize. Plant Soil, 258, 261 268. doi: 10.1023/B:PLSO.0000016556.79278.7f

[31] Motsara M.R. and Roy R.N. 2006. Guide to laboratory establishment for plant nutrient analysis: FAO Fertilizer and plant nutrition bulletin No. 19: 53.

[32] Panaullah J., Timsina M.A., Saleque A.B.M.B.U., Pathan D.J., Connor P.K., Shaha M.A., Quayyum E.
H. and Meisner, C.A. 2006. Nutrient uptake and apparent balances for rice-wheat sequences. III. Potassium. J. Plant Nutr. 29: 173-187.

[33] Patterson G. 2002. Potassium nutrition in plants. Factsheet No. 89.

[34] PDA (2015). Soil Texture and pH Effects on Potash and Phosphorus Availability. Potash Development Association, York, UK

[35] RICHARDS L.A, 1954- Diagnosis and improvement of saline and alkali soils .USDA AgricHanbook 60. Washington, D.C.

[36] Romheld V. and Neumann G. 2006. The rhizosphere: contributions of the soil-root interface to sustainable soil systems. In: Biological approaches to sustainable soil systems. Swaminathan, M.S. (Ed.). Taylor and Francis, UK.

[37] Saini J. and Grewal, K.S. 2014. Vertical distribution of different forms of potassium and their relationship with different soil properties in some Haryana soil under different crop rotation. Adv. Plants Agric. Res., 1: $1-5$.

[38] Sonar, K.R. and Patil, Y.M. (1996). Forms of potassium influenced by Geological and Physiography of the soil in Maharastra. J. of Potassium Res. 12 (3): 230-236.

[39] Suddhiprakarn A. A, Chittamart A. N, Kheoruenromne A.I. and Gilkes R.J. 2010. Charge properties and potassium fixation by clay from Thai Vertisols. 19th World Congress of Soil Science, Soil Solutions for a Changing World. pp. 26-29.

[40] Tisdale S.L. and Nelson W.L. 1993. Soil fertility and fertilizers. Macmillan publishing Co., New York, USA. pp. 242-247.

[41] Tripathi, D., Upadhyay, G.P; Bhandari, A. R. and Sharma, U. (1992). Potassium distribution in some orchard soils and Mandi district of Himachal Pradesh. J. of Potassium Res. 8 (3): 264-267.

[42] Usherwood NR 1985: The role of potassium in crop quality. In Potassium in Agriculture, Ed. Munson RD, pp. 489 - 514. American Society of Agronomy, Crop Science Society of America, Soil Science Society of America, Madison, Wisconsin USA.

[43] Walkley A. and Black I.A. 1934. An examination of the method for determining soil organic matter and proposed modification of the chromic acid titration method. Soil Science. 37: 29-28. 
العلاقة بين أشكال البوتاسيوم و الخصائص الفيزيائية و الكيميائية لترب مأخوذة من محافظة حمص

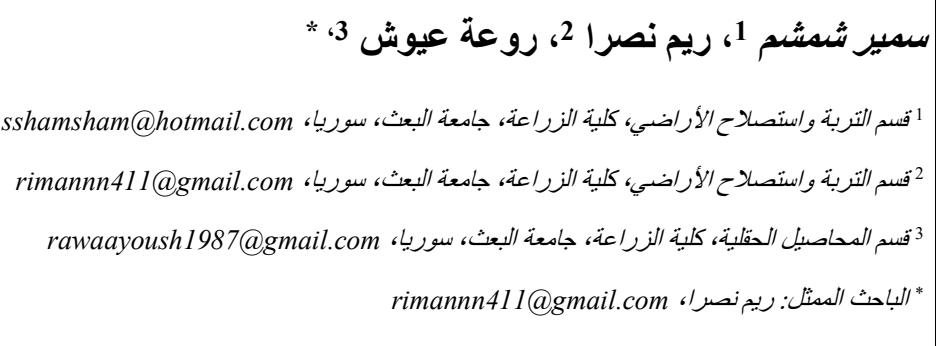
نشر في: 31 آب 2019

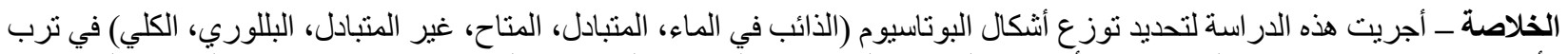

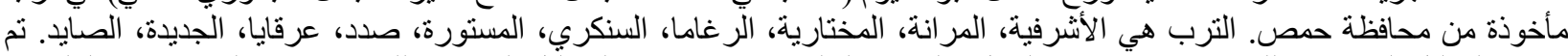

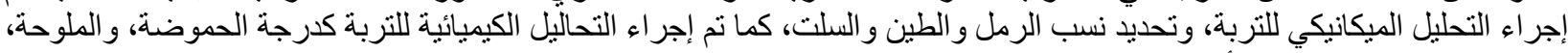

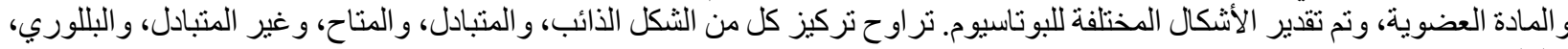

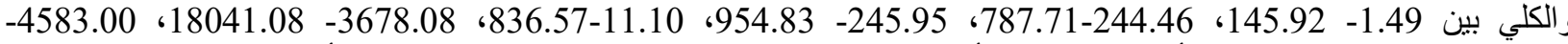

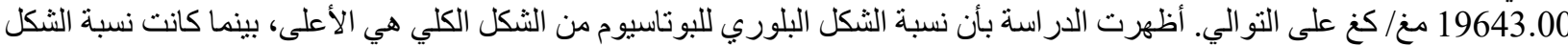

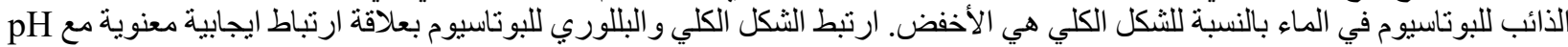

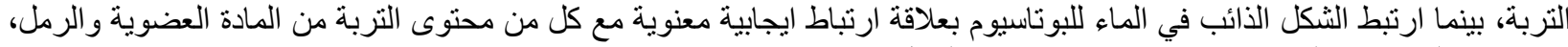

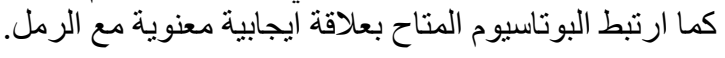
الكلمات الرئيسية ــ التربة، البوتاسيوم، أشكال، البوتاسيوم غير المتبادل، البللوري، المادة العضوية، حمص. 